\title{
Pengembangan Media Edukasi Perlindungan Anak untuk Mengurangi Kekerasan Pada Anak Usia Dini
}

\author{
Devi Risma $^{\varpi_{1}}$, Yeni Solfiah ${ }^{2}$, Defni Satria ${ }^{3}$ \\ Pendidikan Guru Pendidikan Anak Usia Dini, Universitas Riau \\ DOI: $10.31004 /$ obsesi.v4i1.322
}

\begin{abstract}
Abstrak
Penelitian ini dilakukan untuk menghasilkan suatu media edukasi perlindungan anak untuk mengurangi perilaku kekerasan pada anak. Perlindungan anak merupakan permasalahan yang harus mendapatkan perhatian dari setiap pihak. Untuk meningkatkan perlindungan terhadap anak diperlukan suatu media edukasi yang dapat digunakan dengan mudah oleh setiap pihak, baik oleh orang tua, guru, maupun anak tersebut. Media edukasi yang dihasilkan dalam penelitian ini adalah dalam bentuk buku cerita bergambar. Berdasarkan hasil uji validasi oleh tiga orang ahli diperoleh hasil sebesar 95\% dalam kategori sangat baik. Hasil uji lapangan pada 15 orang tua, 14 orang guru, dan 11 orang anak juga diketahui bahwa media edukasi buku bergambar sangat baik dan dapat dipahami dari segi cover, isi, dan tampilan buku cerita. berdasarkan hasil analisis data maka dapat disimpulkan bahwa buku cerita seri perlindungan anak sangat baik, sehingga dapat digunakan untuk meningkatkan pengetahuan orang tua, guru, dan anak tentang perlindungan anak sehingga dapat mengurangi perilaku kekerasan pada anak.
\end{abstract}

Kata Kunci : media edukasi; perlindungan anak; kekerasan anak; anak usia dini

\begin{abstract}
This research was conducted to produce educational media for child protection to reduce violent behavior in children. Child protection is an issue that must get the attention of every party. To increase protection for children an educational media is needed that can be used easily by each party, both by parents, teachers, and children. Educational media produced in this study were in the form of picture storybooks. According to the results of the validation test by three experts obtained results of $95 \%$ in the very good criterion. The results of the field test on 15 parents, 14 teachers, and 11 children were also known that the picture book education media were very good and could be understood in terms of the cover, content, and appearance of storybooks. Based on the results of data analysis, it can be concluded that the child protection series storybooks are very good and can be used to increase the knowledge of parents, teachers, and children about child protection to reduce violent behavior in children.
\end{abstract}

Keywords : educational media; child protection; child abuse; early childhood

Copyright (c) 2019 Devi Risma, Yeni Solfiah, Defni Satria

$\triangle$ Corresponding author:

Email Address : devi.risma@lecturer.unri.ac.id (Pekanbaru, Riau)

Received 12 September 2019, Accepted 7 December 2019, Published 23 December 2019 


\section{PENDAHULUAN}

Anak merupakan titipan dari Tuhan yang harus dijaga sebaik-baiknya. Anak merupakan harapan dari setiap keluarga sebagai generasi penerus harapan keluarga, yang berarti sebagai generasi penerus suatu bangsa dan peradaban. Sebagai generasi penerus, anak harus tumbuh dan berkembang dengan optimal pada semua aspek perkembangannya baik fisik maupun psikis. Untuk mencapai pertumbuhan dan perkembangan anak secara optimal, tentunya anak harus memperoleh perlindungan dari segala bentuk kekerasan terhadap anak. Dengan demikian hak anak akan dapat terpenuhi dengan baik. Pelaksanaan perlindungan terhadap anak adalah tanggung jawab semua lapisan masyarakat, dimulai dari lingkungan masyarakat terkecil yaitu keluarga.

Penyelenggaraan perlindungan anak sesuai dengan amanat Undang-undang No. 35 Tahun 2014 tentang Perlindungan Anak dan Konvensi Hak Anak. Namun pengertian tentang anak menjadi suatu permasalahan di Indonesia, karena terdapat perbedan pengertian tentang anak pada peraturan-peraturan maupun perundang-undangan yang berlaku di Indonesia. Tidak samanya pengertian tentang anak menyebabkan berbedanya penerapan peraturan perundang-undangan dan dapat saling tumpang tindih antara satu dengan yang lainnya (Indriati, Wahyuningsih, S, \& S, 2018).

Perlindungan anak menjadi tanggung jawab semua masyarakat, bukan hanya keluarga. Semua lapisan masyarakat mempunyai peran dan bertanggung jawab dalam pelaksanaan perlindungan anak, sesuai dengan amanat Undang-undang No. 35 tahun 2014 tentang perubahan atas Undang-undang No. 23 Tahun 2002 tentang perlindungan anak. Menurut UU No. 35 tahun 2014 Tim Visi Yustisia, 2016 (Risma, Solfiah, \& Satria, 2018) pengertian anak adalah seseorang yang belum berusia 18 tahun, termasuk anak yang masih berada dalam kandungan. UU Perlindungan Anak No. 35 Tahun 2014 menyatakan bahwa perlindungan anak adalah segala kegiatan untuk menjamin dan melindungi anak dan hakhaknya agar dapat hidup, tumbuh, berkembang, dan berpartisipasi, secara optimal sesuai dengan harkat dan martabat kemanusiaan, serta mendapat perlindungan dari kekerasan dan diskriminasi.

Berdasarkan pemahaman dari Undang-undang di atas maka dapat dijelaskan bahwa perlindungan anak adalah segala kegiatan yang bermaksud untuk menjamin terpenuhinya hak anak dan melindungi hak anak. Menjamin terpenuhinya hak anak berkaitan dengan terjaminnya hak anak untuk hidup, berpartisipasi, tumbuh, dan berkembang dalam setiap lingkup kehidupannya. Sedangkan perlindungan terhadap hak anak berkaitan dengan perlindungan terhadap anak dari perilaku kekerasan dan diskriminasi. Sehingga ketika anak mendapatkan perlindungan berarti akan membentuk anak-anak yang berkualitas, berakhlak mulia, bahagia dan sejahtera. Hal ini memberi arti akan membentuk generasi penerus yang berkualitas untuk meningkatkan kualitas bangsa Indonesia (Risma et al., 2018).

Isu perlindungan anak sudah menjadi isu dunia. Setiap negara diwajibkan untuk merancang dan melaksanakan strategi perlindungan anak untuk mengurangi kekerasan pada anak. Pendapat (Zumbach, Wetzels, \& Koglin, 2018) menyatakan bahwa perlindungan anak merupakan tantangan yang penting daripada permasalahan sosial dan hukum di suatu negara, karena ketika anak mendapatkan perlakuan kekerasan akan menyebabkan anak dalam keadaan bahaya yang akan mengakibatkan maladaptasi perkembangan dan psikologis anak tersebut.

Menurut data kependudukan jumlah anak di Indonesia adalah sepertiga dari jumlah penduduk Indonesia, yaitu sekitar 85 juta jiwa. Namun masih banyak dewasa (pemerintah, masyarakat, guru, dan orang tua) yang memandang anak sebagai objek yang tentunya bertentangan dengan prinsip-prinsip perlindungan anak. Walaupun menurut hasil penelitian (Risma et al., 2018) diketahui tingkat pengetahuan orang tua tentang perlindungan anak di Provinsi Riau termasuk dalam kategori yang tinggi. Data ini menunjukkan bahwa pada dasarnya masyarakat terutama orang tua mengetahui tentang 
prinsip perlindungan anak, namun pada kenyataannya masih banyak orang tua yang melakukan kekerasan pada anak dengan dalih merupakan bagian dari pendidikan anak. Seringkali orang tua menganggap bahwa memberi hukuman pada anak selama tidak berlebihan dan tidak melukai anak secara fisik adalah hal yang wajar dan dibolehkan dalam pendidikan anak. Hal ini menyebabkan kasus kekerasan terhadap anak terus menerus terjadi secara berulang.

Didukung dengan pernyataan Suradi (Satriawan, Alfiana, Fasya, Amelia, \& Yani, 2017) yang mengatakan bahwa kekerasan pada anak merupakan fenomena sosial yang semakin hari semakin meningkat dan memburuk, baik secara kuantitatif maupun kualitatif. Angka-angka yang ditampilkan secara kuantitatif belum menggambarkan keadaan kasus kekerasan anak sebenarnya, karena masih banyak kasus-kasus kekerasan yang tidak terlaporkan dan tidak terungkap di ruang public dengan berbagai alasan.

Kekerasan atau penganiayaan pada anak terdiri dari kekeraan fisik, seksual, atau psikologis serta pengabaian yang dilakukan terhadap anak yang dilakukan oleh orang tua, atau pengasuh. Perilaku kekerasan termasuk tindakan atau kegagalan dalam pengasuhan yang menyebabkan kerusakan pada anak, perilaku tersebut dapat terjadi di rumah, sekolah, organisasi, maupun komunitas yang berinteraksi dengan anak (Boroujerdi, Kimiaee, Yazdi, \& Safa, 2019). Kekerasan pada anak yang terwujud dalam perlakuan salah terhadap anak (childabuse) sering disamakan dengan kekerasan yang dapat dilihat, seperti kekerasan fisik dan kekerasan seksual. Padahal, masih ada bentuk kekerasan lainnya, yaitu kekerasan psikologis dan kekerasan sosial yang bersifat struktural. Kekerasan fisik berkaitan dengan pemukulan, penyiksaan, dan penganiayaan terhadap anak dengan menggunakan ataupun tanpa menggunakan alat tertentu. Kekerasan psikis berkaitan dengan perilaku menghardik, penyampaian kata-kata kotor, dan lain sebagainya. Kekerasan seksual berkaitan dengan prakontak atau perlakuan seksual pada anak. Sedangkan kekerasan sosial berkaitan dengan penelantaran dan eksploitasi terhadap anak. Eksploitasi terhadap anak terjadi dalam dua bentuk, yaitu eksploitasi ekonomi dan eksploitasi seksual. Eksploitasi ekonomi biasanya terjadi ketika anak diminta untuk bekerja dengan dalih membantu orang tua untuk menambah penghasilan keluarga. Demikian juga dengan eksploitasi seksual, dimana anak dijadikan objek pemenuhan hasrat seksual. Kekerasan-kekerasan tersebut sering secara tidak disadari dilakukan oleh keluarga dan masyarakat terhadap anak.

(Mulyana, Resnawaty, \& Kamil Basar, 2018) menyatakan bahwa angka kekerasan pada anak di Indonesia setiap tahun semakin meningkat. Berdaarkan data Komisi Perlindungan Anak Indonesia (KPAI) tahun 2016 tercatat ada 1000 kasus kekerasan pada anak, dimana 136 kasus disebabkan karena pengaruh media sosial, seperti bully di media sosial. Dalam dunia pendidikan kasus bullying juga semakin meningkat, baik anak sebagai korban maupun sebagai pelaku. Pusat data dan informasi (Pusdatin) Komnas Anak menerima 2898 kasus kekerasan pada anak. Dari jumlah tersebut diketahui sebesar 60\% merupakan kasus kekerasan seksual pada anak. Sedangkan 40\% lainnya adalah kasus kekerasan fisik, penelantaran, penganiayaan, pemerkosaan, adopsi illegal, penculikan, perdagangan dan eksploitasi terhadap anak. Data kekerasan pada anak juga diketahui bahwa sebesar $62 \%$ pelaku kekerasan terhadap anak adalah orang-orang yang berada di sekitar lingkungan anak.

Secara nasional, Provinsi Riau merupakan peringkat kedua kasus kekerasan pada anak setelah Jawa Timur. Yang menarik dari kasus kekerasan ini adalah kekerasan yang terjadi dalam lingkungan keluarga. Kekerasan pada anak dalam keluarga seringkali dianggap hal yang wajar sebagai bagian dari pendidikan anak. Seringkali orang tua menganggap bahwa memberi hukuman selama tidak berlebihan dan membuat anak terluka merupakan sesuatu yang boleh dilakukan untuk membuat anak jera.

Menurut data yang diperoleh dari P2TP2A Pekanbaru tahun 2018 (Sikumbang, 2018) diketahui bahwa Pekanbaru sebagai ibukota Provinsi Riau menempati urutan tertinggi kasus kekerasan anak di Provinsi Riau. Jumlah kasus kekerasan pada anak tahun 2018 di 
kota Pekanbaru sebanyak 105 kasus. Sebanyak 81 kasus anak menjadi korban kekerasan fisik dan seksual. Jumlah tersebut belum termasuk kasus yang ditangani oleh lembaga lainnya (Setyawan, 2019). Dari jumlah tersebut masih banyak data kasus kekerasan yang belum terlaporkan, sehingga dibutuhkan strategi pelaporan kasus pelecehan anak untuk dapat membantu meningkatkan perlindungan anak dan mengaitkan dengan layanan keluarga pada anak-anak yang mengalami kekerasan (Afifi, McTavish, Turner, MacMillan, \& Wathen, 2018).

Berdasarkan hasil penelitian (Risma et al., 2018) diketahui bahwa tingkat pendidikan mempengaruhi perilaku kekerasan terhadap anak. Demikian juga hasil penelitian lain diketahui bahwa tingkat pendidikan berhubungan dengan tingkat pengetahuan orang tua tentang perlindungan anak. Diketahui juga bahwa pada dasarnya tingkat pengetahuan orang tua tentang perlindungan anak berada dalam kategori tinggi, yang berarti bahwa pada dasarnya orang tua mengetahui bahwa anak harus melindungi anak untuk pemenuhan hak-hak anak. Namun perilaku kekerasan pada anak dalam kategori sedang, hasil penelitian ini menunjukkan bahwa walaupun pengetahuan orang tua tentang perlindungan anak tinggi, namun masih banyak terdapat orang tua yang melanggar pemenuhan hak anak. Hal ini dapat disebabkan karena strategi pelaksanaan perlindungan anak yang belum tepat. Pelaksanaan perlindungan anak perlu memperhatikan pandangan orang tua tentang layanan perlindungan anak, sehingga evaluasi terhadap layanan perlindungan anak dapat menjadi efektif. Seperti hasil pendapat (Tilbury \& Ramsay, 2018) diketahui bahwa kepuasan dan ketidakpuasan orang tua terhadap pelayanan perlindungan anak berhubungan dengan keterampilan para pelaksana perlindungan anak, intervensi yang diberikan, serta aspek sistem perlindungan anak itu sendiri. Keadaan tersebut juga hal yang masih terjadi di Indonesia.

Penelitian tentang perlindungan anak sudah banyak dilakukan, namun angka kekerasan pada anak dari tahun ke tahun semakin meningkat. Di sisi lain sosialisasi tentang perlindungan anak sudah banyak dilakukan oleh pemerintah melalui iklan dan promosi layanan masyarakat yang ditampilkan di media elektronik, maupun poster atau balihobaliho yang dipasang di sepanjang jalan. Selain itu juga sudah banyak masyarakat yang melakukan edukasi tentang perlindungan anak, terutama tentang pendidikan seks. Namun edukasi tersebut terlalu singkat, sehingga masyarakat masih banyak yang belum mendapatkan pemahaman secara menyeluruh tentang penyelenggaraan perlindungan anak dan macam-macam kekerasan pada anak. Media maupun buku-buku tentang penyelenggaraan anak secara menyeluruh belum ditemukan. Oleh karena itu pada penelitian ini peneliti mengembangkan media edukasi yang menarik untuk orang tua dan guru tentang perlindungan anak, agar orang tua dan guru mempunyai pemahaman yang utuh berkaitan dengan perlindungan anak. Media ini juga dapat digunakan untuk mengembangkan pengetahuan anak tentang kekerasan pada anak, sehingga diharapkan anak dapat lebih waspada terhadap perlakuan salah yang dilakukan oleh orang dewasa di sekitarnya.

\section{METODOLOGI}

Jenis penelitian ini adalah penelitian dan pengembangan (Research and Development). Pada penelitian pengembangan ini yang dilakukan adalah membuat suatu produk berupa media edukasi tentang perlindungan anak untuk mengurasi perilaku kekerasan pada anak. Media edukasi yang dihasilkan dalam bentuk buku cerita bergambar. Rancangan penelitian pengembangan ini adalah dengan memodifikasi desain penelitian pengembangan dari Robert Maribe Branch (dalam Sugiyono, 2017) yang dikenal dengan Model ADDIE (Analysis, Design, Development, Implementation, Evaluation) 


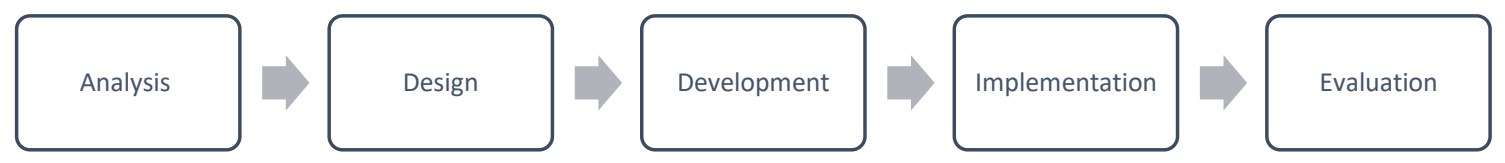

Gambar 3.1 Prosedur Penelitian Menurut Robert Maribe Branch (Sugiyono, 2017)

Tahap analis berkaitan dengan pelaksanaan kegiatan analisis terhadap situasi lapangan dan lingkungan sehingga dapat ditemukan media edukasi apa yang perlu dikembangkan. Pada tahap desain, peneliti merancang produk yang akan dibuat sesuai dengan kebutuhan masyarakat, terutama untuk orang tua dengan anak usia dini. Tahap development merupakan tahap pelaksanaan pembuatan dan pengujian produk. Pada tahap development yang dikembangkan adalah media edukasi dalam bentuk buku cerita bergambar. Pengujian produk pada tahap awal dilakuan dengan melakukan uji validasi pada ahli, yaitu ahli psikologi, PAUD, dan ahli Bahasa Indonesia. Setelah melakukan revisi berdasarkan saran ahli, maka dilanjutkan pada tahap implementation. Pada tahap implementation merupakan tahap penggunaan produk. Produk berupa buku cerita bergambar yang telah direvisi diujicobakan pada pengguna, yaitu orang tua, guru, dan anak usia dini. Tahap terakhir adalah tahap evaluasi. Pada tahap ini peneliti melakukan perbaikan berdasarkan penilaian dari pengguna terhadap produk (buku cerita seri perlindungan anak). Setelah direvisi buku cerita seri perlindungan anak kemudian dilakukan validasi kedua dari para ahli, setelah direvisi berdasarkan masukan dari ahli maka produk media edukasi buku cerita seri perlindungan anak siap untuk dicetak dan disebarkan pada masyarakat.

Sampel pada penelitian ini terdiri dari orang tua, guru, dan anak di TK Labor FKIP Universitas Riau sebagai sampel pengguna media edukasi perlindungan anak. Pengambilan data dilakukan secara kuantitatif dan kualitatif. Data kuantitatif diperoleh dari hasil penilaian terhadap media edukasi yang diujicobakan di lapangan. Sedangkan data kualitatif didapatkan dari hasil observasi dan wawancara pada ahli, orang tua, guru, dan anak.

\section{HASIL DAN PEMBAHASAN}

\section{Hasil}

Penelitian dan pengembangan ini disusun berdasarkan hasil pengamatan dan analisis kebutuhan dan kasus, serta studi literatur tentang perlindungan anak. Penelitian ini menghasilkan media edukasi dalam bentuk buku seri cerita bergambar yang bertujuan untuk meningkatkan pemahaman orang tua tentang perlindungan anak sehingga dapat mengurangi perilaku kekerasan pada anak.. Buku seri perlindungan anak terdiri dari empat judul buku, yaitu; (1) Tolong Jangan Sakiti Aku; (2) Jangan Bentak Aku; (3) Ajari Aku Lindungi Tubuh; dan (40 Biarkan Aku Bermain.

Tahapan pembuatan buku cerita dimulai dari pembuatan rancangan naskah buku cerita dalam bentuk tulisan tangan yang disusun oleh tim peneliti. Naskah cerita dalam bentuk tulisan tangan seperti gambar 1 berikut ini.
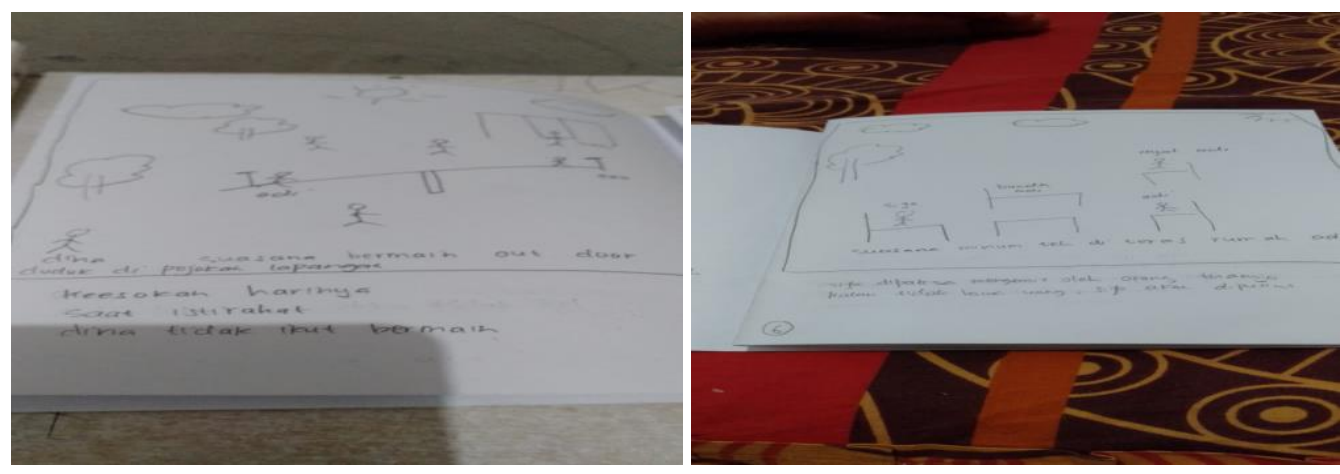

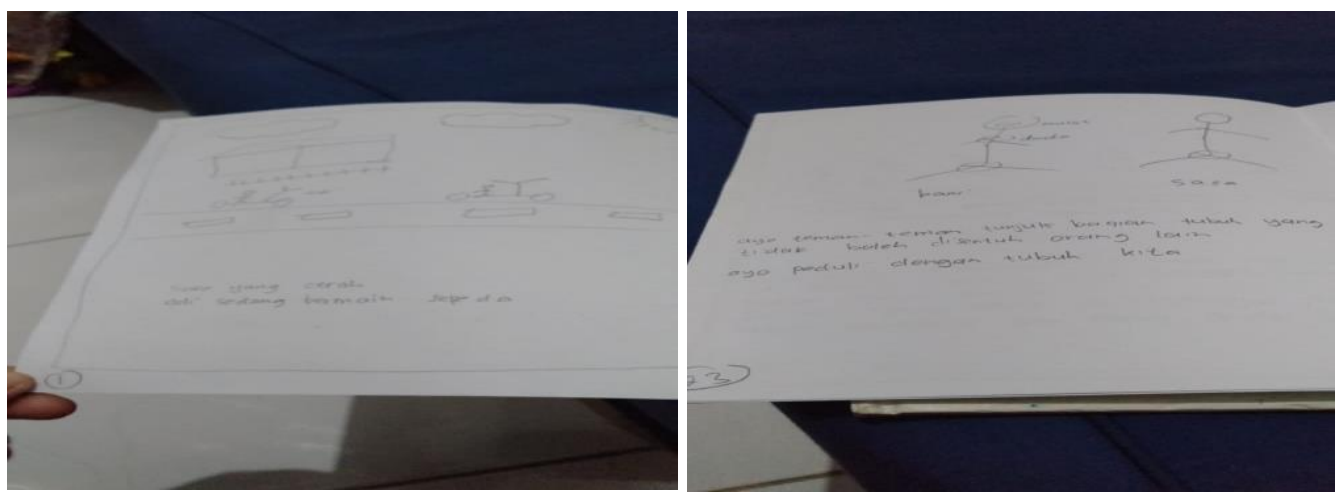

Gambar 1. Rancangan Awal Buku Seri Perlindungan Anak

Setelah dibuat naskah cerita dan ilustrasi gambar secara manual menggunakan pensil selanjutnya rancangan dibuat atau didesain menggunakan komputerisasi dengan menggunakan aplikasi Corel Draw. Berikut ini adalah rancangan media buku cerita bergambar yang menggunakan sistem komputerisasi :
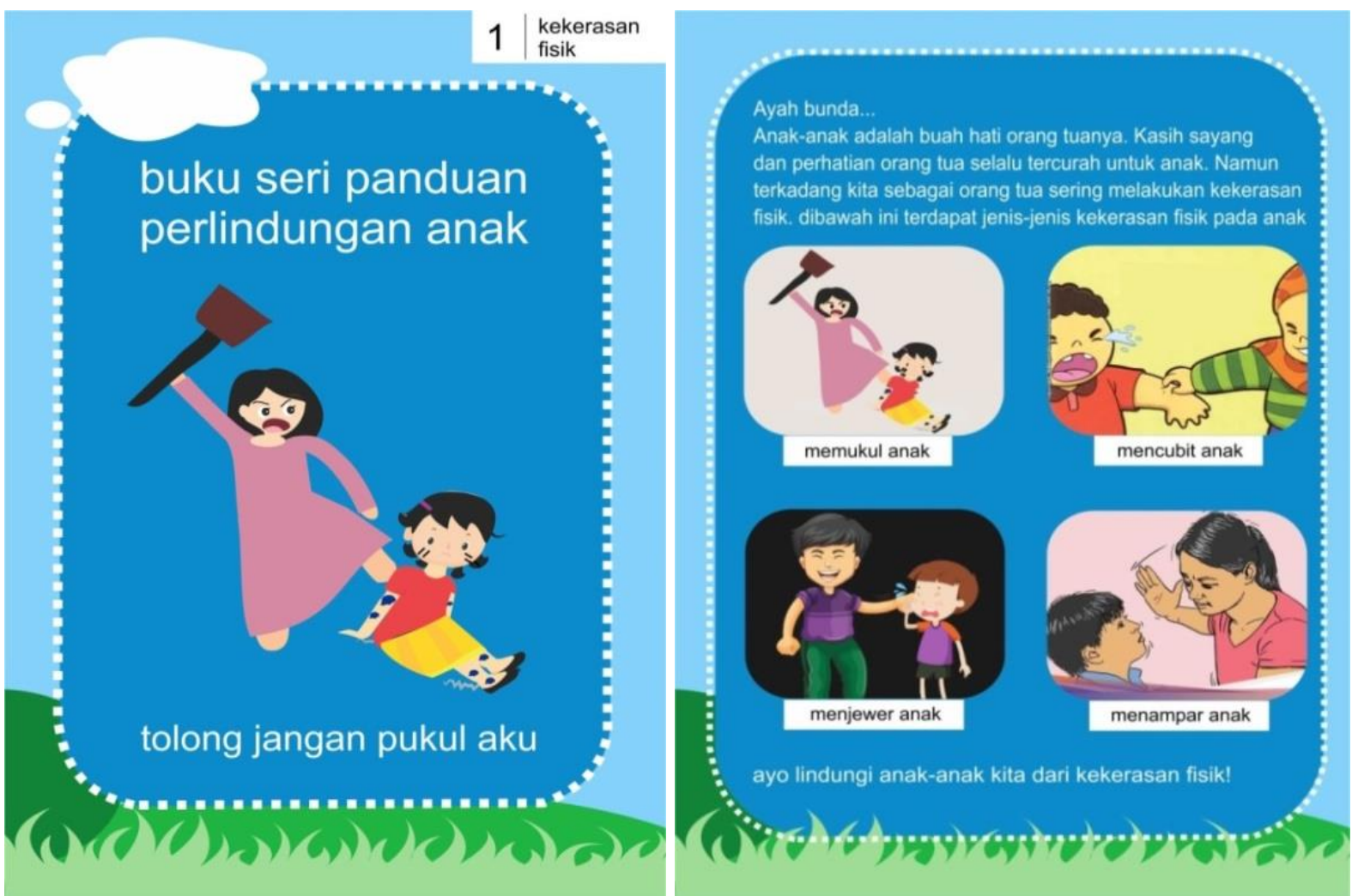

Gambar 2. Rancangan 2 Buku Seri Perlindungan Anak 

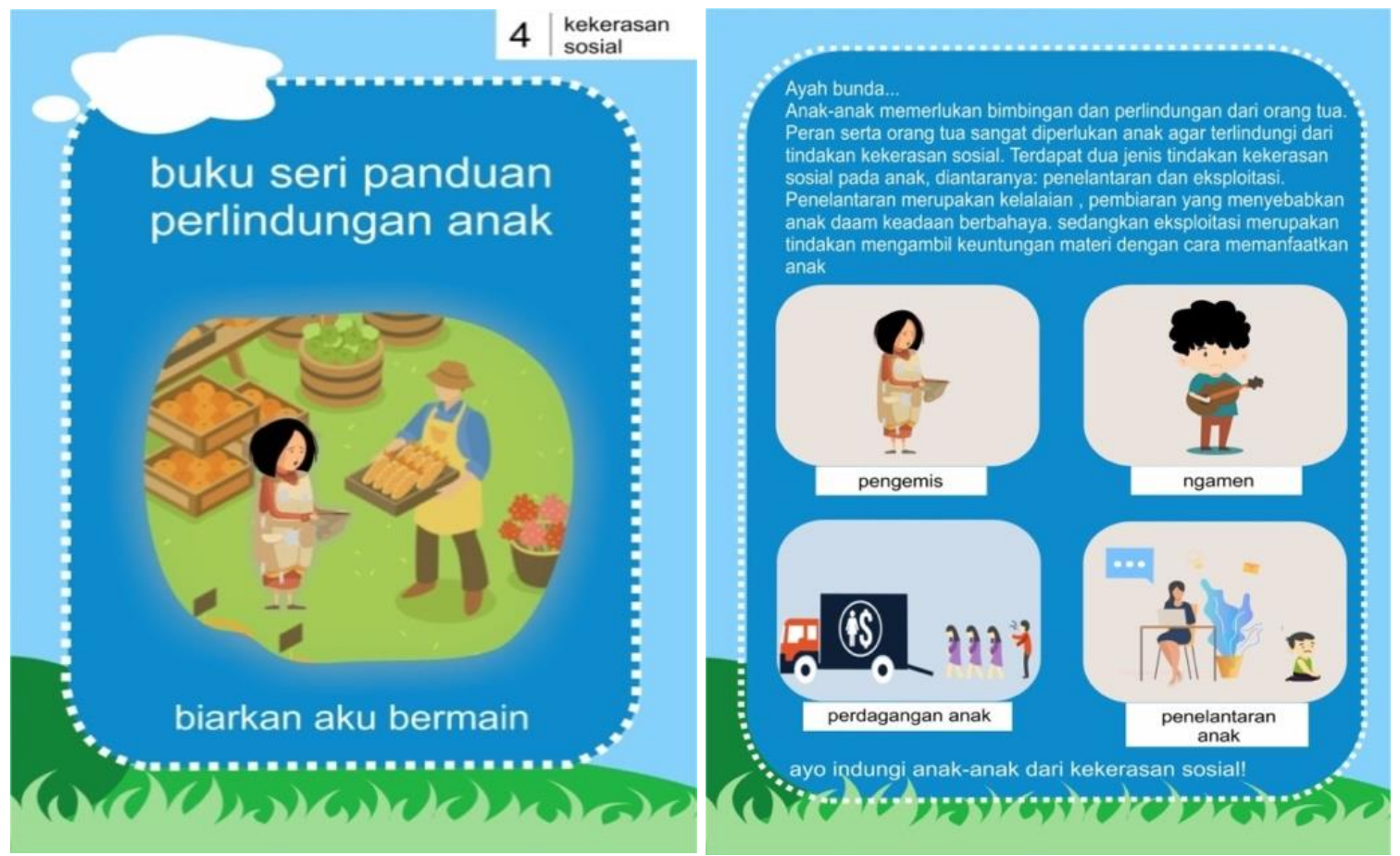

Gambar 3. Rancangan 2 Buku Seri Perlindungan Anak
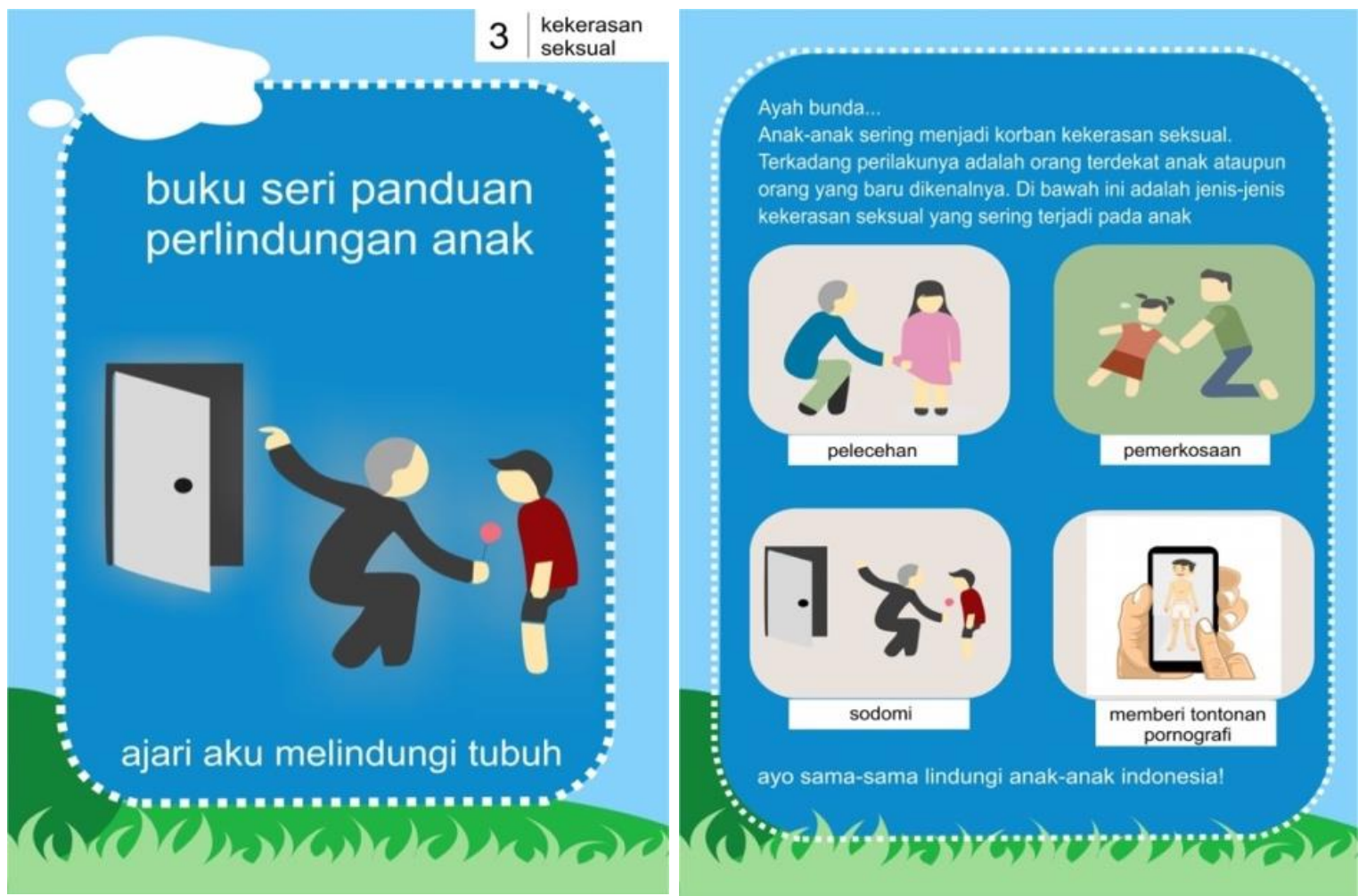

Gambar 4. Rancangan 2 Buku Seri Perlindungan Anak 

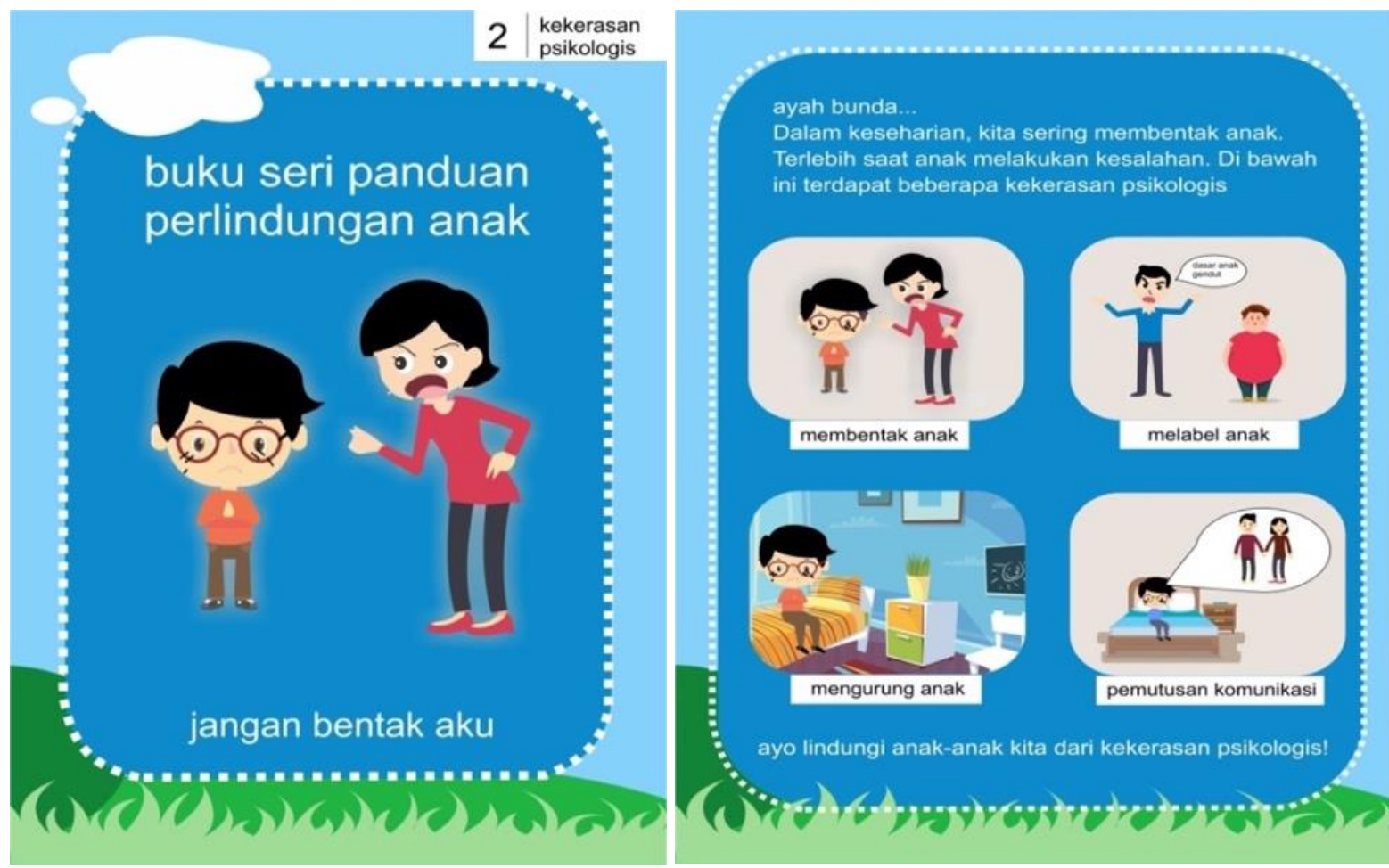

Gambar 5. Rancangan 2 Buku Seri Perlindungan Anak

\section{Uji Kelayakan Buku Cerita Seri Perlindungan Anak}

\section{Uji Validasi Ahli Pertama}

Setelah buku cerita seri perlindungan anak selesai dibuat, maka dilakukan uji validasi pada ahli yang berkaitan, yaitu seorang psikolog, ahli PAUD, dan ahli bahasa. Hasil uji validasi ahli digambarkan pada tabel 1 berikut.

Tabel 1. Uji Validasi Ahli

\begin{tabular}{|c|c|c|c|c|c|c|c|}
\hline Ahli & No & Aspek & $\begin{array}{l}\text { Jumlah } \\
\text { Item }\end{array}$ & $\begin{array}{l}\text { Skor } \\
\text { Ideal }\end{array}$ & $\begin{array}{l}\text { Skor } \\
\text { Faktual }\end{array}$ & $\%$ & Kategori \\
\hline \multirow{4}{*}{ Psikologi } & 1 & Cover & 3 & 15 & 13 & $86,67 \%$ & Sangat Baik \\
\hline & 2 & $\begin{array}{l}\text { Isi Buku } \\
\text { Cerita }\end{array}$ & 7 & 35 & 31 & $88,57 \%$ & Sangat Baik \\
\hline & 3 & $\begin{array}{l}\text { Bentuk } \\
\text { Tampilan }\end{array}$ & 6 & 30 & 25 & $83,33 \%$ & Sangat Baik \\
\hline & \multicolumn{2}{|c|}{ Sub Jumlah } & 16 & 80 & 69 & $86,25 \%$ & Sangat Baik \\
\hline \multirow{4}{*}{ PAUD } & 1 & Cover & 3 & 15 & 13 & $86,67 \%$ & Sangat Baik \\
\hline & 2 & $\begin{array}{l}\text { Isi Buku } \\
\text { Cerita }\end{array}$ & 7 & 35 & 29 & $82,86 \%$ & Sangat Baik \\
\hline & 3 & $\begin{array}{l}\text { Bentuk } \\
\text { Tampilan }\end{array}$ & 6 & 30 & 26 & $86,67 \%$ & Sangat Baik \\
\hline & \multicolumn{2}{|c|}{ Sub Jumlah } & 16 & 80 & 68 & $85,00 \%$ & Sangat Baik \\
\hline \multirow{5}{*}{$\begin{array}{l}\text { Bahasa } \\
\text { Indonesia }\end{array}$} & 1 & Cover & 3 & 15 & 13 & $86,67 \%$ & Sangat Baik \\
\hline & 2 & $\begin{array}{l}\text { Isi Buku } \\
\text { Cerita }\end{array}$ & 7 & 35 & 30 & $85,71 \%$ & Sangat Baik \\
\hline & 3 & $\begin{array}{l}\text { Bentuk } \\
\text { Tampilan }\end{array}$ & 6 & 30 & 25 & $83,33 \%$ & Sangat Baik \\
\hline & \multicolumn{2}{|c|}{ Sub Jumlah } & 16 & 80 & 68 & $85,00 \%$ & Sangat Baik \\
\hline & \multicolumn{2}{|c|}{ Jumlah } & 16 & 240 & 205 & $85,42 \%$ & Sangat Baik \\
\hline
\end{tabular}


Dari tabel 1 dapat dilihat bahwa buku cerita seri perlindungan anak sangat baik dengan nilai $85,42 \%$. Hasil tersebut juga disertai dengan masukan-masukan secara kualitatif dari para ahli. Setelah dilakukan revisi pada buku cerita maka buku cerita seri perlindungan anak diuji coba pada masyarakat.

\section{Uji Lapangan}

Setelah mendapatkan masukan dari ahli dan melakukan revisi, maka peneliti menguji coba buku cerita seri perlindungan anak kepada pengguna, yaitu kepada orang tua, guru dan anak. Berdasarkan hasil uji coba dapat digambarkan pada tabel 2, 3, dan 4.

Tabel 2. Penilaian Orang Tua pada Buku Cerita Bergambar tentang Perlindungan

\begin{tabular}{lcccccc}
\multicolumn{1}{c}{ Indikator } & $\begin{array}{c}\text { Jumlah } \\
\text { Item }\end{array}$ & $\begin{array}{c}\text { Skor } \\
\text { Faktual }\end{array}$ & $\begin{array}{c}\text { Skor } \\
\text { Ideal }\end{array}$ & Rata-Rata & $\mathbf{\%}$ & Kategori \\
\hline Cover Buku & 3 & 68 & 75 & 13,60 & $90,67 \%$ & Sangat Baik \\
Isi Cerita Buku & 7 & 159 & 175 & 31,80 & $90,86 \%$ & Sangat Baik \\
$\begin{array}{l}\text { Bentuk } \\
\text { Tampilan Buku }\end{array}$ & 6 & 126 & 150 & 25,20 & $84,00 \%$ & Sangat Baik \\
\hline Jumlah & $\mathbf{1 6}$ & $\mathbf{3 5 3}$ & $\mathbf{4 0 0}$ & $\mathbf{7 0 , 6 0}$ & $\mathbf{8 8 , 2 5 \%}$ & Sangat Baik \\
\hline
\end{tabular}

Tabel 3. Penilaian Guru pada Buku Cerita Bergambar tentang Perlindungan Anak

\begin{tabular}{lcccccc}
\hline \multicolumn{1}{c}{ Indikator } & $\begin{array}{c}\text { Jumlah } \\
\text { Item }\end{array}$ & $\begin{array}{c}\text { Skor } \\
\text { Faktual }\end{array}$ & $\begin{array}{c}\text { Skor } \\
\text { Ideal }\end{array}$ & Rata-Rata & $\mathbf{\%}$ & Kategori \\
\hline Cover Buku & 3 & 67 & 75 & 13,40 & $89,33 \%$ & Sangat Baik \\
$\begin{array}{l}\text { Isi Cerita Buku } \\
\text { Bentuk }\end{array}$ & 7 & 140 & 175 & 28,00 & $80,00 \%$ & Sangat Baik \\
Tampilan Buku & 6 & 132 & 150 & 26,40 & $88,00 \%$ & Sangat Baik \\
\hline Jumlah & $\mathbf{1 6}$ & $\mathbf{3 3 9}$ & $\mathbf{4 0 0}$ & $\mathbf{6 7 , 8 0}$ & $\mathbf{8 4 , 7 5 \%}$ & Sangat Baik \\
\hline
\end{tabular}

Tabel 4. Penilaian Anak pada Buku Cerita Bergambar tentang Perlindungan Anak

\begin{tabular}{lcccccc}
\hline \multicolumn{1}{c}{ Indikator } & $\begin{array}{c}\text { Jumlah } \\
\text { Item }\end{array}$ & $\begin{array}{c}\text { Skor } \\
\text { Faktual }\end{array}$ & $\begin{array}{c}\text { Skor } \\
\text { Ideal }\end{array}$ & Rata-Rata & $\mathbf{\%}$ & Kategori \\
\hline Cover Buku & 3 & 68 & 75 & 13,60 & $90,67 \%$ & Sangat Baik \\
$\begin{array}{l}\text { Isi Cerita Buku } \\
\text { Bentuk }\end{array}$ & 7 & 162 & 175 & 32,40 & $92,57 \%$ & Sangat Baik \\
Tampilan Buku & 6 & 125 & 150 & 25,00 & $83,33 \%$ & Sangat Baik \\
\hline Jumlah & $\mathbf{1 6}$ & $\mathbf{3 5 5}$ & $\mathbf{4 0 0}$ & $\mathbf{7 1 , 0 0}$ & $\mathbf{8 8 , 7 5 \%}$ & Sangat Baik \\
\hline
\end{tabular}

Berdasarkan tabel di atas, buku cerita bergambar tentang perlindungan anak, baik dari segi cover buku, isi cerita buku, dan bentuk tampilan buku termasuk kategori sangat baik. Data diperoleh dari 40 orang responden, yaitu 15 orang tua, 14 orang guru, dan 11 orang anak. Penilaian dari orang tua sebesar $88,25 \%$ dengan kategori sangat baik, penilaian dari guru sebesar $84,75 \%$ dengan kategori sangat baik dan penilaian dari anak sebesar $88,75 \%$ dengan kategori sangat baik.

\section{Uji Validasi Ahli Kedua}

Walaupun berdasarkan hasil uji lapangan diketahui buku cerita seri perlindungan anak tersebut mendapatkan penilaian yang sangat baik, namun para responden juga memberikan masukan yang berarti. Berdasarkan masukan-masukan dari responden, maka peneliti melakukan revisi terhadap buku cerita seri perlindungan anak. Setelah dilakukan revisi, peneliti melakukan validasi kedua pada ahli untuk mengetahui apakah buku seri 
perlindungan anak tersebut layak untuk digunakan. Hasil uji validasi ahli kedua dapat dilihat pada Tabel 5 berikut.

Tabel 5. Uji Validasi Ahli Kedua

\begin{tabular}{|c|c|c|c|c|c|c|c|}
\hline Ahli & No & Aspek & $\begin{array}{c}\text { Jumlah } \\
\text { Item }\end{array}$ & $\begin{array}{l}\text { Skor } \\
\text { Ideal }\end{array}$ & $\begin{array}{c}\text { Skor } \\
\text { Faktual }\end{array}$ & $\%$ & Kategori \\
\hline \multirow{4}{*}{ Psikolog } & 1 & Cover & 3 & 15 & 14 & $93,33 \%$ & Sangat Baik \\
\hline & 2 & $\begin{array}{c}\text { Isi Buku } \\
\text { Cerita }\end{array}$ & 7 & 35 & 34 & $97,14 \%$ & Sangat Baik \\
\hline & 3 & $\begin{array}{l}\text { Bentuk } \\
\text { Tampilan }\end{array}$ & 6 & 30 & 29 & $96,67 \%$ & Sangat Baik \\
\hline & \multicolumn{2}{|c|}{ Sub Jumlah } & 16 & 80 & 77 & $96,25 \%$ & Sangat Baik \\
\hline \multirow{4}{*}{ PAUD } & 1 & Cover & 3 & 15 & 15 & $100,00 \%$ & Sangat Baik \\
\hline & 2 & $\begin{array}{l}\text { Isi Buku } \\
\text { Cerita }\end{array}$ & 7 & 35 & 33 & $94,29 \%$ & Sangat Baik \\
\hline & 3 & $\begin{array}{c}\text { Bentuk } \\
\text { Tampilan }\end{array}$ & 6 & 30 & 28 & $93,33 \%$ & Sangat Baik \\
\hline & \multicolumn{2}{|c|}{ Sub Jumlah } & 16 & 80 & 76 & $95,00 \%$ & Sangat Baik \\
\hline \multirow{5}{*}{$\begin{array}{c}\text { Bahasa } \\
\text { Indonesia }\end{array}$} & 1 & Cover & 3 & 15 & 15 & $100,00 \%$ & Sangat Baik \\
\hline & 2 & $\begin{array}{l}\text { Isi Buku } \\
\text { Cerita }\end{array}$ & 7 & 35 & 32 & $91,43 \%$ & Sangat Baik \\
\hline & 3 & $\begin{array}{c}\text { Bentuk } \\
\text { Tampilan }\end{array}$ & 6 & 30 & 28 & $93,33 \%$ & Sangat Baik \\
\hline & \multicolumn{2}{|c|}{ Sub Jumlah } & 16 & 80 & 75 & $93,75 \%$ & Sangat Baik \\
\hline & \multicolumn{2}{|c|}{ umlah } & 16 & 240 & 228 & $95,00 \%$ & Sangat Baik \\
\hline
\end{tabular}

Berdasarkan Tabel 5 diketahui bahwa buku cerita seri perlindungan anak sudah sangat baik dengan nilai 95\%, sehingga buku seri perlindungan anak tersebut layak untuk dipublikasikan pada masyarakat. Hasil validasi kedua dari para ahli ini merupakan validasi final dari buku cerita seri perlindungan anak. Naskah final dari buku cerita seri perlindungan anak dapat dilihar dari gambar 8, 9, 10, 11 .
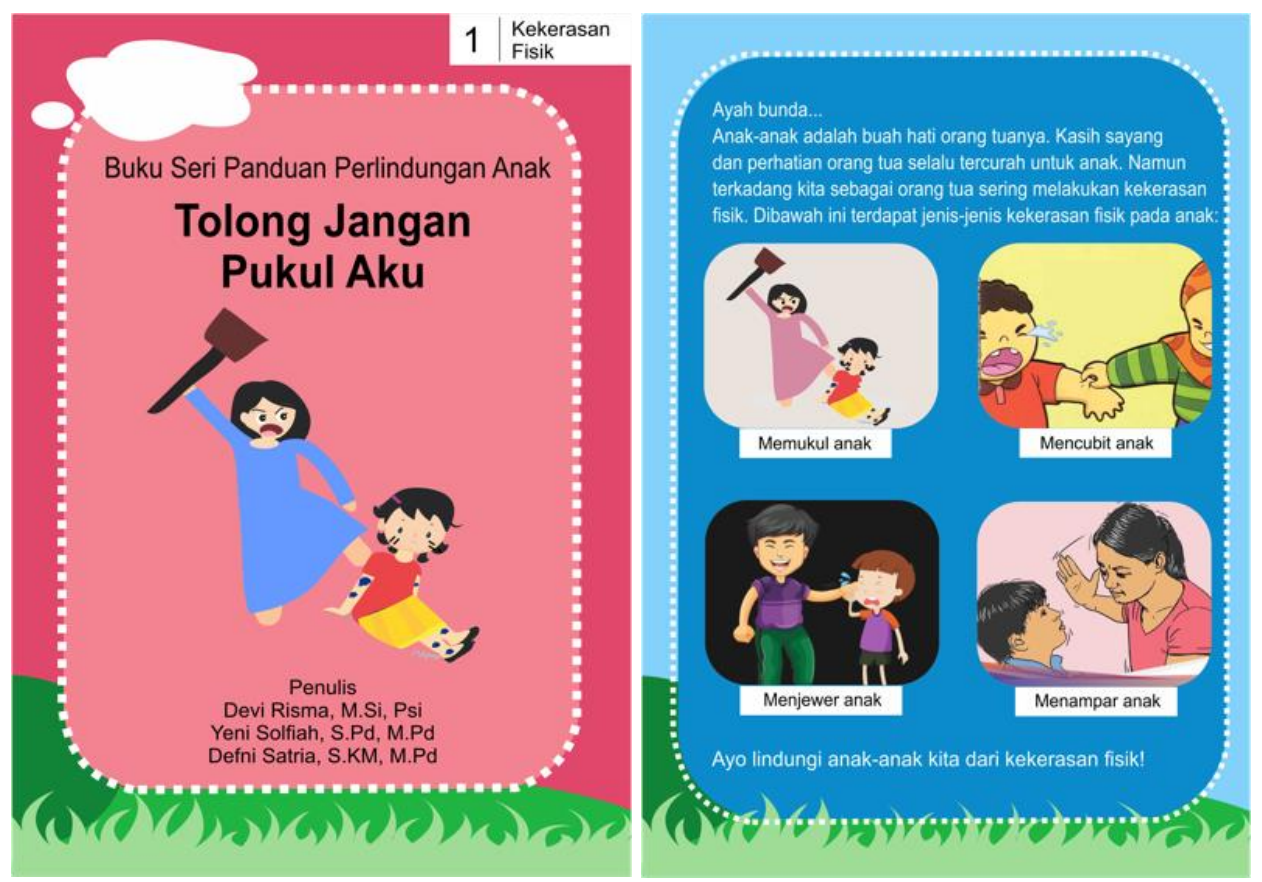

Gambar 8. Naskah Final Buku Cerita Seri Perlindungan Anak 


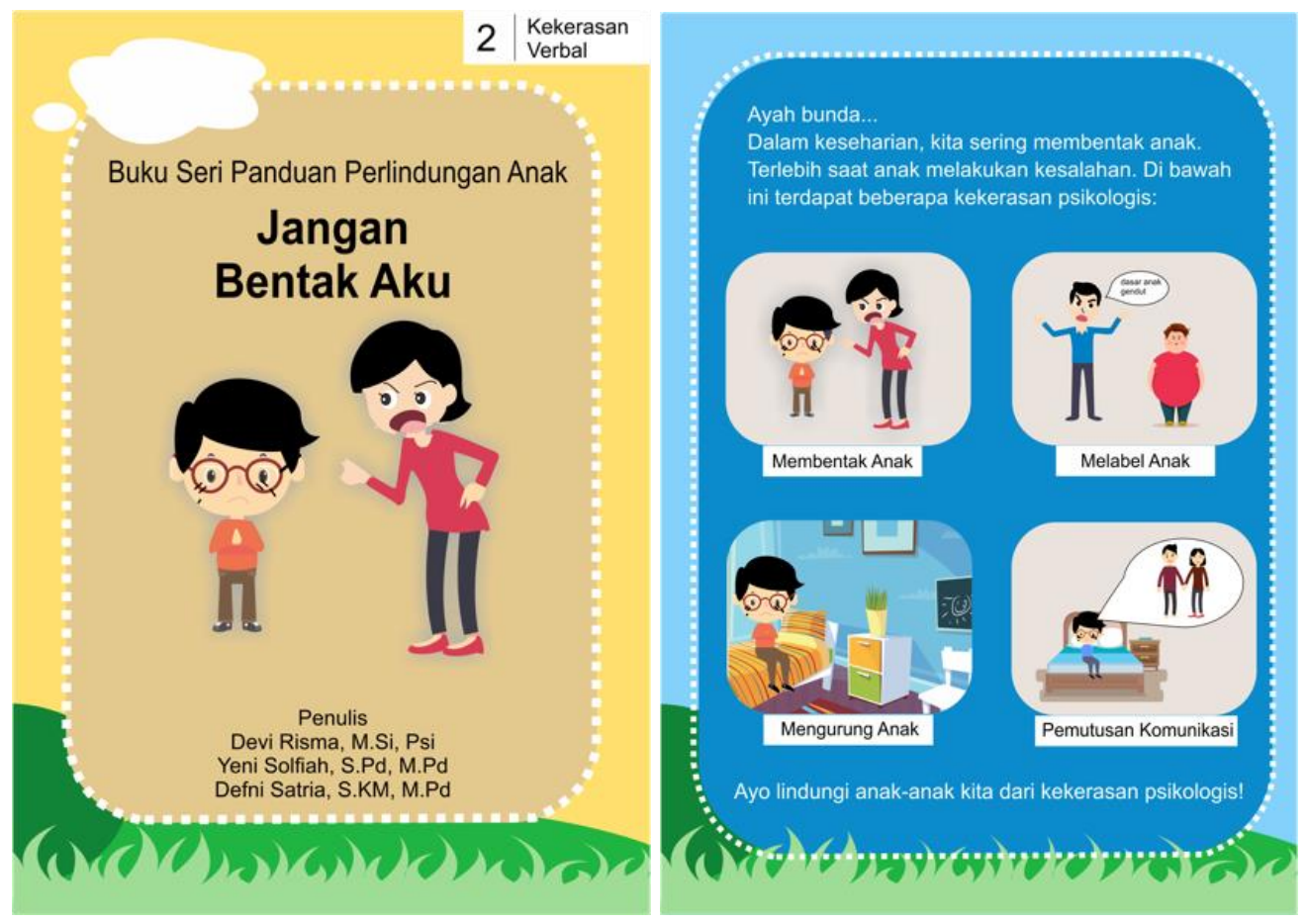

Gambar 9. Naskah Final Buku Cerita Seri Perlindungan Anak
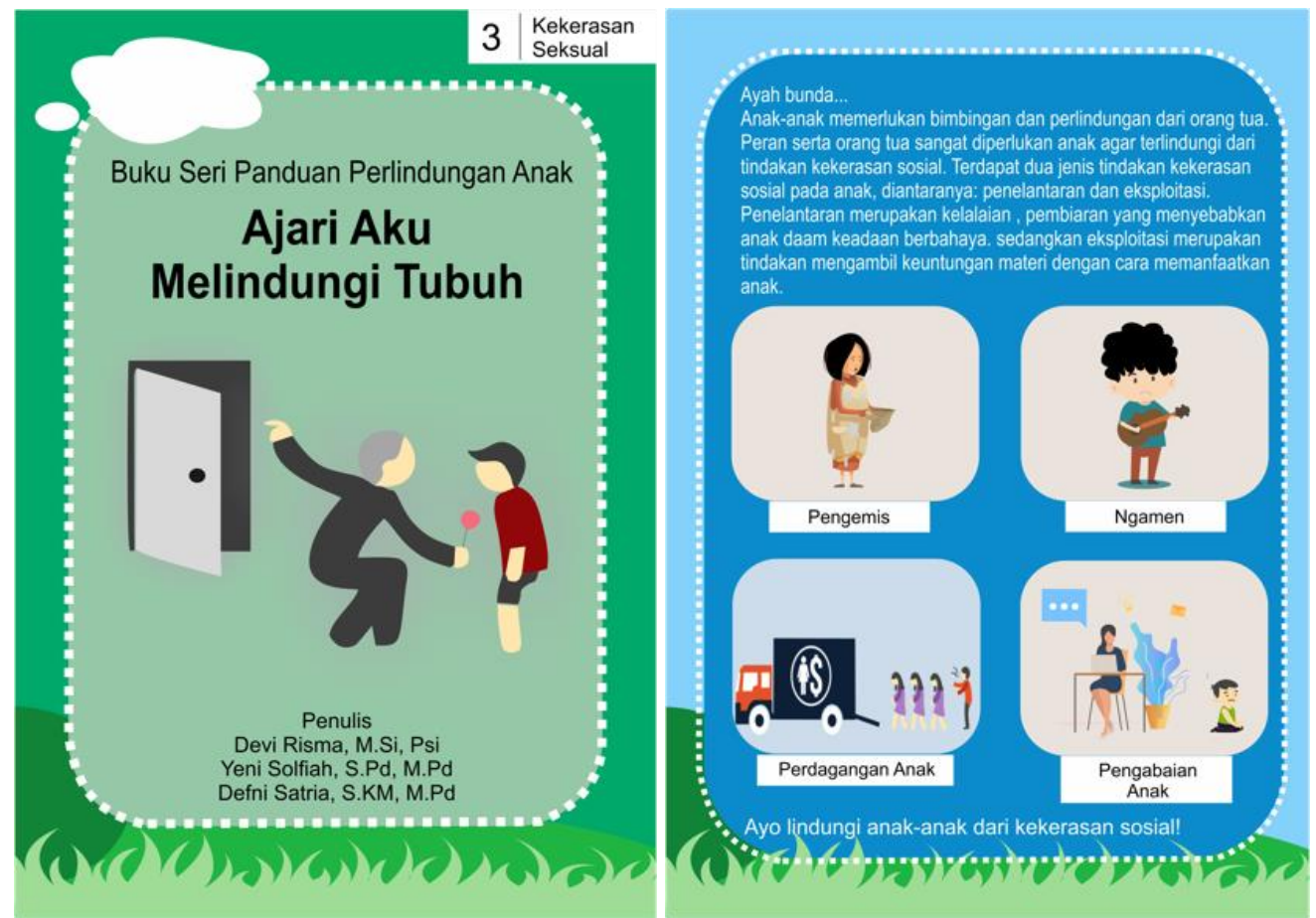

Gambar 9. Naskah Final Buku Cerita Seri Perlindungan Anak 


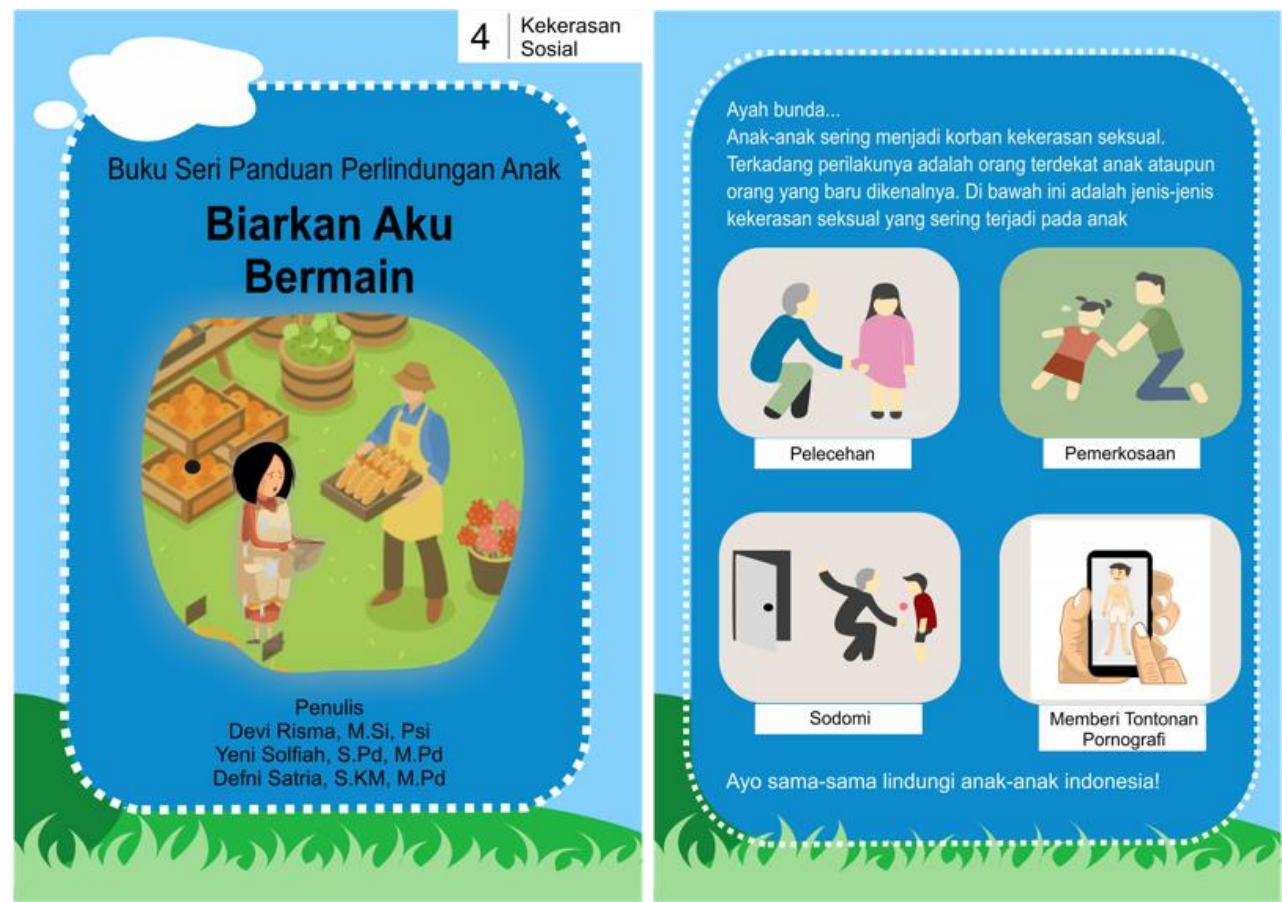

Gambar 10. Naskah Final Buku Cerita Seri Perlindungan Anak

\section{Pembahasan}

Penelitian pengembangan ini menggunakan langkah-langkah pengembangan dari Borg dan Gall (dalam Sugiono, 2017). Dalam penelitian ini penulis mengembangkan buku cerita bergambar tentang kekerasan fisik, psikologis, seksual dan sosial. Buku cerita bergambar ini menceritakan tentang kekerasan yang sering dialami oleh anak. Isi dari buku cerita bergambar ini menggambarkan bagaimana orang tua atau orang dewasa lainnya sering melanggar hak anak. Menurut (Kumar, Kar, \& Kumar, 2019) pelecehan terhadap adalah hal umum yang terjadi, sehingga penanganan terhadap pelecehan anak merupakan kebutuhan mendesak untuk meningkatkan kesadaran masyarakat tentang perlindungan anak. Diperlukan prioritas regulasi pelayanan untuk mendukung pelaksanaan perlindungan anak yang mudah diakses oleh anak-anak.

Regulasi pelaksanaan perlindungan anak menjadi perhatian penting pada setiap negara. Seperti di negara Cina, menurut hasil penelitian (Man, Barth, Li, \& Wang, 2017) diketahui ada lima elemen dasar dari sistem perlindungan anak yang akan dijadikan percontohan untuk mengetahui bagaimana sistem berjalan di negara tersebut. Elemen tersebut terdiri dari: (1) Program percontohan perlindungan anak bertujuan lebih melayani anak-anak yang lebih rentan daripada anak-anak yang mengalami pelecehan dan pengabaian, (2). Walaupun kantor pelayanan perlindungan anak telah ada, namun tanggung jawab perlindungan anak ada pada setiap Lembaga, (3) Sistem pelaporan yang jelas untuk melaporkan kasus dugaan pelecehan anak telah dianjurkan dalam praktek pelaksanaan perlindungan anak, serta (4) Organisasi dan Lembaga perlindungan anak domestik memainkan peran penting dalam menyediakan layanan perawatan alternatif terhadap anak yang mengalami kekerasan, (5). Walaupun telah dibentuk sistem perlindungan anak, namun masih terdapat hambatan yang signifikan dalam pelaksanaan perlindungan anak. Temuan tersebut menunjukkan bahwa untuk efektivitas penyelenggaraan perlindungan anak tidak hanya dibutuhkan regulasi sistem kebijakan yang tepat, namun juga sangat tergantung kepada perhatian semua masyarakat untuk berkontribusi dalam pelaksanaan perlindungan anak.

Dalam buku cerita bergambar ini juga menceritakan bagaimana dampak yang dialami oleh anak jika mereka mendapatkan kekerasan. Salah satu contohnya adalah kekerasan fisik, jika anak mendapatkan kekerasan fisik dampaknya adalah rasa ketakutan, ada bekas akibat kekerasan terkadang anak bisa mengalami gangguan atau kerusakan organ 
tubuhnya. Demikian juga dengan jenis kekerasan lain yang tentunya juga memberikan dampak negatif dalam perkembangan anak. Menurut hasil penelitian (Nindya, 2012) menunjukkan bahwa kekerasan emosional mempunyai hubungan dengan kecenderungan perilaku kenakalan remaja. Anak-anak yang mendapatkan kekerasan cenderung akan memiliki perilaku yang menyimpang ketika memasuki usia remaja. Selain itu (Putri \& Santoso, 2012) juga menjelaskan bahwa kekerasan verbal juga memunculkan akibat yang tidak kalah buruknya dengan kekerasan fisik. Biasanya ketika orang tua melakukan kekerasan fisik seperti memukul, mencubit, dan menjewer hampir selalu diikuti dengan perilaku kekerasan verbal seperti membentak, berteriak, dan melecehkan anak. Namun menurut hasil penelitian (Putri \& Santoso, 2012) ini juga menjelaskan bahwa orang tua berpendapat bahwa kekerasan verbal memberikan dampak yang tidak terlalu berat dibandingkan dengan kekerasan fisik. Selain itu (Di, Yongjie, \& Guowei, 2018) juga menemukan bahwa segala bentuk kekerasan pada anak akan menimbulkan trauma psikologis yang luar biasa dan dapat mempengaruhi kesejahteraan psikologis anak.

Berdasarkan kajian-kajian tersebut maka diperlukan suatu media edukasi untuk meningkatkan pemahaman orang tua tentang perlindungan anak dan kekerasan anak. Buku cerita bergambar ini merupakan salah satu bentuk media edukasi untuk penyelenggaraan perlindungan anak, dengan membaca buku cerita bergambar ini benar- benar dapat meningkatkan pengetahuan dan pemahaman orang tua, guru dan anak. Hal ini sesuai dengan pendapat yang dikemukakan oleh Hamalik (Zaini \& Dewi, 2017) bahwa media pembelajaran akan memudahkan interaksi antara guru dan anak, sehingga kegiatan pembelajaran dapat berjalan secara efektif dan efisien. Sedangkan Sardiman (Zaini \& Dewi, 2017) menyatakan bahwa media pembelajaran merupakan segala hal yang digunakan untuk menyampaikan materi ajar serta dapat merangsang perasaan, perhatian, pikiran, dan kemauan anak sehingga dapat mendukung terjadinya proses belajar dalam diri individu.

Supaya buku cerita bergambar memiliki kualitas, peneliti melakukan validasi dari validator ahli, adapun masukannya yaitu pembuatan cover di setiap seri warnanya dibedakan, warna harus terang dan mencolok, gambar harus sesuai dengan naskah cerita. Sesuai dengan pendapat Rothlein dan Meinbach (Adipta, Maryaeni, \& Hasanah, 2016) dijelaskan bahwa buku cerita bergambar merupakan buku yang berupa ilustrasi untuk mengungkapkan pesan melalui gambar dan tulisan yang membentuk suatu kesatuan yang utuh. Menurut Huck (Tarigan, 2018) buku cerita yang dibuat untuk anak haruslah sesuai dengan sudut pandang anak, sehingga akan meningkatkan pemahaman anak terhadap bacaan yang dibaca.

Pengembangan media edukasi perlindungan anak ini bertujuan untuk mengurangi angka kekerasan terhadap anak. Pada dasarnya perlindungan anak merupakan upaya agar anak memahami hakikat perlindungan anak dan meningkatkan resiliensinya, dengan demikian akan dapat membantu anak untuk dapat mengatasi kekerasan yang akan dan atau diterimanya. Melalui media edukasi buku cerita bergambar tentang perlindungan anak ini diharapkan orang tua mampu memberikan umpan balik yang postif terhdap perilaku yang dimunculkan anak, serta dapat memberikan dukungan kepada anak melalu struktur, stabilitas, dan konsistensi dalam aturan. Dengan demikian kekerasan pada anak akan dapat dikurangi (Rijbroek, Strating, Konijn, \& Huijsman, 2019).

Hasil dari uji lapangan terhadap orang tua, guru dan anak, dilihat dari segi cover buku, isi cerita buku, dan bentuk tampilan buku termasuk kriteria sangat baik. Penilaian dari orang tua sebesar $88,25 \%$ dengan kategori sangat baik, penilaian dari guru sebesar $84,75 \%$ dengan kriteria sangat baik dan penilaian dari anak sebesar 88,75\% dengan kriteria sangat baik. Hasil ini menunjukkan bahwa buku cerita bergambar ini sangat layak digunakan untuk meningkatkan pemahaman tentang perlindungan anak.

Beberapa pendapat dari orang tua dan guru tentang buku cerita bergambar ini yaitu isi buku cerita sudah sangat baik, sehingga dapat membantu dalam mendidik anak dan lebih berhati- hati dalam menjaga diri. Isi buku cerita mudah dipahami dan berdampak positif. 
Buku cerita bergambar ini menginspirasi bagaimana seharusnya memperlakukan anak, bagaimana cara memberi tahu dengan halus dan lembut sesuatu kepada anak. Untuk penggunaan tanda baca juga salah satu masukan dari orang tua dan guru. Setelah dilakukan perbaikan sesuai saran dari orang tua, guru, dan anak maka peneliti melakukan revisi terhadap buku cerita perlindungan anak. Setelah direvisi peneliti kembali melakukan uji validasi final kepada ahli dan diperoleh hasil sebesar 95\%. Dengan demikian maka buku cerita seri perlindungan anak tersebut sudah layak untuk disebarkan pada masyarakat.

\section{SIMPULAN}

Penelitian ini menghasilkan empat buku cerita seri perlindungan anak, yaitu buku perlindungan anak tentang kekerasan fisik, kekerasan psikologis, kekerasan sosial, serta kekerasan seksual. Dari hasil uji validasi ahli diperoleh hasil penilaian sangat baik, yang berarti bahwa buku cerita seri perlindungan anak ini layak untuk digunakan oleh masyarakat. Berdasarkan uji lapangan pada orang tua, guru, dan anak juga diperoleh hasil penilaian yang sangat baik terhadap cover, isi, tampilan dari buku cerita. Orang tua dan guru juga berpendapat bahwa buku cerita bergambar ini dapat menambah pengetahuan dan pemahaman mereka tentang hal-hal perlindungan anak, khususnya tentang perilaku kekerasan pada anak.

\section{UCAPAN TERIMA KASIH}

Penelitian ini didanai sepenuhnya oleh Lembaga Penelitian dan Pengabdian (LPPM) Universitas Riau. Peneliti juga mengucapkan terima kasih kepada Dr. Daviq Chairilsyah, M. Psi., Dr. Rita Kurnia, M. Ed., dan Dr. Hermandra, MA., yang telah memberikan masukan terhadap buku cerita perlindungan anak. Terima kasih juga peneliti ucapkan kepada Mhd. Sanusi, Yandes Tri Simorangkir, Repsi Mei Atalia, serta seluruh pihak yang terlibat dalam penyelesaian penelitian ini.

\section{DAFTAR PUSTAKA}

Adipta, H., Maryaeni, M., \& Hasanah, M. (2016). Pemanfaatan buku cerita bergambar sebagai sumber bacaan siswa SD. Jurnal Pendidikan - Teori, Penelitian, Dan Pengembangan, 1(5), 989-992. https:/ / doi.org/10.17977/jp.v1i5.6337

Afifi, T. O., McTavish, J., Turner, S., MacMillan, H. L., \& Wathen, C. N. (2018). The relationship between child protection contact and mental health outcomes among Canadian adults with a child abuse history. Child Abuse and Neglect, 79(February), 22-30. https:// doi.org/10.1016/j.chiabu.2018.01.019

Boroujerdi, F. G., Kimiaee, S. A., Yazdi, S. A. A., \& Safa, M. (2019). Attachment style and history of childhood abuse in suicide attempters. Psychiatry Research, 271, 1-7. https:// doi.org/10.1016/j.psychres.2018.11.006

Di, Q., Yongjie, W., \& Guowei, W. (2018). The severity, consequences and risk factors of child abuse in China - An empirical Study of 5836 children in China's mid-western regions. Children and Youth Services Review, 95(October), 290-299. https:// doi.org/10.1016/j.childyouth.2018.10.039

Indriati, N. Y., Wahyuningsih, K. K., S, S., \& S, S. (2018). Perlindungan dan pemenuhan hak anak (Studi tentang orangtua sebagai buruh migran di Kabupaten Banyumas). Mimbar Hukum - Fakultas Hukum Universitas Gadjah Mada, 29(3), 474. https:// doi.org/10.22146/jmh.24315

Kumar, M. T., Kar, N., \& Kumar, S. (2019). Prevalence of child abuse in Kerala, India: An ICAST-CH based survey. Child Abuse and Neglect, 89(January), 87-98. https:// doi.org/10.1016/j.chiabu.2019.01.002

Man, X., Barth, R. P., Li, Y., \& Wang, Z. (2017). Exploring the new child protection system in Mainland China: How does it work? Children and Youth Services Review, 76, 196-202. https:// doi.org/10.1016/j.childyouth.2017.03.012 
Mulyana, N., Resnawaty, R., \& Kamil Basar, G. G. (2018). Penanganan anak korban kekerasan. Al-Izzah: Jurnal Hasil-Hasil Penelitian, 13(1), 77. https:/ / doi.org/10.31332/ai.v13i1.871

Nindya, P. N. (2012). Hubungan Kekerasan Emosional pada Anak terhadap Kecenderugan Kenakalan Remaja. P. N. Nindya, 1(02), 1-9.

Putri, A. M., \& Santoso, A. (2012). Persepsi Orang Tua Tentang Kekerasan Verbal Pada Anak. Diponegoro Journal of Nursing, 1(1), 22-29.

Rijbroek, B., Strating, M. M. H., Konijn, H. W., \& Huijsman, R. (2019). Child protection cases, one size fits all? Cluster analyses of risk and protective factors. Child Abuse $\mathcal{E}$ Neglect, 95, 104068. https:// doi.org/10.1016/j.chiabu.2019.104068

Risma, D., Solfiah, Y., \& Satria, D. (2018). Hubungan tingkat pendidikan orang tua dengan bentuk kekerasan terhadap anak. https://doi.org/ISSN : 2089-7510

Satriawan, Alfiana, Fasya, H., Amelia, A. F., \& Yani, A. A. (2017). Analisis kebijakan perlindungan kekerasan terhadap anak di kota Makasar, 3(1), 1-13. Retrieved from http://journal.unhas.ac.id/index.php/jakpp/article/view/4067/2329

Setyawan, D. (n.d.). KPAI sebut pelanggaran hak anak terus meningkat. Retrieved December 6, 2019, from https://www.kpai.go.id/berita/kpai-sebut-pelanggaran-hak-anak-terusmeningkat

Sikumbang, F. (n.d.). 105 Anak dan perempuan di Pekanbaru alami Kekerasan, 81 anak korban kekerasan seksual dan fisik. Retrieved October 28, 2019, from https://pekanbaru.tribunnews.com/2018/12/28/105-anak-dan-perempuan-dipekanbaru-alami-kekerasan81-anak-korban-kekerasan-seksual-dan-fisik

Tarigan, N. T. (2018). Pengembangan Buku Cerita Bergambar Untuk Meningkatkan Minat Baca Siswa Kelas Iv Sekolah Dasar. Jurnal Curere / Vol.02 / No. 02 / Oktober 2018, 02(02), 141-152. Retrieved from http://www.portaluniversitasquality.ac.id:5388/ojssystem/index.php/CURERE/articl e/viewFile/157/130

Tilbury, C., \& Ramsay, S. (2018). A systematic scoping review of parental satisfaction with child protection services. Evaluation and Program Planning, 66, 141-146. https://doi.org/10.1016/j.evalprogplan.2017.10.010

Zaini, H., \& Dewi, K. (2017). Pentingnya media pemebelajaran untuk anak usia dini. Raudhatul Athfal: Jurnal Pendidikan Islam Anak Usia Dini, 1(1), 81-96. https://doi.org/10.19109/ra.v1i1.1489

Zumbach, J., Wetzels, P., \& Koglin, U. (2018). Predictors of psychological recommendations in child protection evaluation. Child Abuse $\mathcal{E}$ Neglect, 84, 196-204. https://doi.org/10.1016/j.chiabu.2018.08.003 